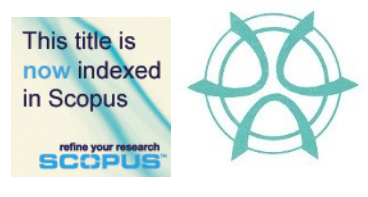

PLANNING MALAYSIA:

Journal of the Malaysian Institute of Planners

VOLUME 18 ISSUE 2 (2020), Page 261 - 272

\title{
URBAN LIVABILITY INDICATORS FOR SECONDARY CITIES IN ASEAN REGION
}

\author{
M. Rafee Majid ${ }^{1}$, D. G. Pampanga ${ }^{2}$, Musarrat Zaman ${ }^{3}$, Noradila Ruslik ${ }^{4}$, I.N. Medugu ${ }^{5}$, M.S. Amer \\ 1,4,6 Faculty of Built Environment and Surveying \\ UNIVERSITI TEKNOLOGI MALAYSIA \\ ${ }^{2}$ Graduate School \\ UNIVERSITY OF MINDANAO \\ ${ }^{3}$ Faculty of Social Sciences \\ BANGLADESH UNIVERSITY OF PROFESSIONALS \\ ${ }^{5}$ Faculty of Environmental Science \\ NASARAWA STATE UNIVERSITY, NIGERIA
}

\begin{abstract}
Urban livability indicators have tremendous influence on policies and growth trajectories of cities or metropolises to the benefit of their communities. Livability is a threshold for measuring the social dimension of people wrought by exogenous factors like infrastructure, environment, social cohesion, transportation, health and education, among others. This research is aimed to generate prototype urban livability indicators for secondary cities in Southeast Asia, benchmarked on the livability indicators of Iskandar Malaysia, Davao City in the Philippines and Makassar in Indonesia. A three-round iterative Delphi survey (scoping, convergence, and consensus) was conducted to pre-qualified 60 experts with equal representations from the three metropolises. The significant phase was the scoping where experts have to supplement the given framework for their aspired urban livability sub-indicators under specific domain indicators. In the convergence phase, reconsideration of sub-indicators and preliminary ranking of domain indicators using the 5-point Likert Scale's degree of agreement and Kendall's W coefficient of concordance were performed. In the consensus phase, both domain indicators and sub-indicators were ranked separately and assigned corresponding weightings. With the total of 108 framework-based and supplementary sub-indicators categorized under the 11 domain indicators, the study conclusively yielded 75 common, comparative, interconnected, and consistent urban livability indicators ranked according to the aspiration of stakeholders in three ASEAN secondary cities. This research, through the employ of robust methodology, has generated comprehensive composite urban livability indicators for secondary metropolitan settlements in Southeast Asia; thus, the resulting final indicators can be potentially engaged to determine a comparative urban livability index of cities in the ASEAN region.
\end{abstract}

Keywords: Urban indicators, ASEAN, urban livability, Southeast Asia, Delphi

\footnotetext{
${ }^{1}$ Professor at Universiti Teknologi Malaysia (UTM); Email: rafee@utm.my
} 
M. Rafee Majid, G. Dario Pampanga, Noradila Ruslik, Musarrat Zaman, I.N. Medugu \& M.S. Amer

Urban Livability Indicators for Secondary Cities in ASEAN Region

\section{INTRODUCTION}

The dynamic reconfiguration of urban settlements brought by the confluence of unrelenting urbanization through demographic shifts from rural to urban areas, growth of natural population, and sustained economic affluence continue to alter the traditional spatial and social landscapes of cities in ASEAN (Association of Southeast Asian Nation) region. Added to these are the consequential effects of unmanaged environmental issues as well as impacts of climate change especially to urban centers with so much to lose in terms of lives and properties. Evidently, the convergence of these challenges defines clear manifestation that livability of urban centers is at risk. Thus, the need for enhanced urban livability-based metrics to be embedded in policy-making would steer policy shifts, including the required livability-driven urban infrastructures and services are necessary inputs to create and sustain urban livability in Southeast Asian cities and metropolises.

\section{Livability and Livable City}

Livability denotes to the subset of sustainability impacts (Litman, 2011) that directly affects people's lives in a community such socio-cultural, economic development and well-being, and including the protection of the environment of present inhabitants and the future generation (Timmer and Seymoar, 2005; Ji, 2006). Timmer and Seymoar (2005) underscored that comprehensive urban spatial and environmental planning are the key factors towards urban livability, thus sustainable urbanization. Vliet (2002) indicated that available employment should pay a living wage, urban basic services, access to quality educational opportunities, universal health care, decent and affordable housing, clean environment, secure and safe communities, and should be characterized with good governance and the absence of discriminatory norms. On the other hand, Kapoor (2011) gave some positive statements for a livable city that indicates conditions of the urban environment, health facilities, urban infrastructure, and accessibility to recreational facilities.

In sum, a livable city should have the characteristics that satisfy the necessities of its urban residents through the provision of basic infrastructure hardware, with vibrant economy, accessibility to social infrastructure, environment-oriented development paradigm, free from social disorder, the capacity to secure its citizen from the hazards of the changing climate, and cognizant to comprehensive spatial planning.

\section{Some livability conundrums in ASEAN cities}

The rapid urbanization and phenomenal economic growth of most cities in Southeast Asia has been the key driver for an improved quality of life of its urban citizens. However, as the population of ASEAN region continues to be unabated, which is projected to grow $9.5 \%$ to 720 million in 2025 with $46 \%$ of the population living in cities and metropolises by 2020 (UN-Habitat, 2010), key 
urban centers in this region will continue to be plagued by a myriad of livability issues that could potentially obstruct its trajectory toward establishing livable and sustainable urban centers. In the same vein that urbanization increases disparity in income and in social inequality that can adversely affect social capital and cohesion and in the worst of cases exclusion of access to home ownership, education, welfare and healthcare, among others.

Inadequate urban public housing where unabated proliferation of informal settlements in Ho Chi Minh City (UN-Habitat, 2010; ISOCARP, 2010) and the problem of affordability and inequality in Hanoi (Tran and Yip, 2008) continue to exist, while housing quality and access to basic urban services continue to deteriorate in Palembang, Pontianak and Kalimantan in Indonesia (Chomistriana, 2011). Malaysia has to grapple with concern on governance, and decent and affordable housing (UN-Habitat, 2010), while Metro Manila in the Philippines has approximately $43 \%$ of the 13 million people residing in illegal settlements (Steinberg, 2011). In Indonesia, an estimated 65\% of the total urban population has no access to piped water (Asian Trends Monitoring, 2010), Bangkok has inadequate health services and deteriorating sanitation, while Myanmar's urban indicators for health and well-being, compares poorly to other ASEAN countries.

Most Southeast Asian cities are vulnerable to natural calamities such as flooding. Cities in the Philippines, Thailand, Indonesia and Malaysia are prone to coastal flooding. In Southeast Asia, approximately 25.5 million urbanites in 10 cities are at flood risk (ADB, 2012). Issues such as safe streets, adequate urban transportation, accessibility to medical and health institutions, comprehensive land use planning, and the alarming issue on the prevalence of increasing social exclusion which could lead to furtherance of a severe divide between rich and poor, are also prevalent that could hinder the promotion of livability of cities in Southeast Asia.

\section{The significance of indicators}

Indicators communicate movements and patterns in a given society as well as offer prospective action to afford important changes in a community. It is used to monitor and assess a particular situation systematically (Friedman, 2005), while the UN Food and Agriculture Organization stressed that indicators support decision-making and management. It "quantifies and aggregates data that can be measured and monitored to determine whether change is taking place. But in order to understand the process of change, the indicator needs to help decisionmakers understand why change is taking place" (FAO, 2002). Hezri (2004) emphasized that indicators are a mechanism for effective communication and managerial tool used by decision makers (Alibegovic and De Villa, 2008). Livability indicators are vital to operationalize the sustainability concept in planning and the development of the city. More often, architects of indicators 
M. Rafee Majid, G. Dario Pampanga, Noradila Ruslik, Musarrat Zaman, I.N. Medugu \& M.S. Amer

Urban Livability Indicators for Secondary Cities in ASEAN Region

believe that indicators simplify multifaceted sets of data as well as offer distinct perception of the larger image. For planners, measuring urban livability through indicators would enable them to create a livable city as they can put their concentration on areas where there are weaknesses (Balsas, 2004).

The study is a pioneering agglomeration study for Malaysia, the Philippines and Indonesia or conceivably for the ASEAN region. This empirical gap is basically underpinned on the absence of any comprehensive urban livability indicators framework which is significant to the promotion of sustainable urbanization. This endeavors for the establishment of appropriate and well-defined and comprehensive livability indicators anchored within the concepts of comparability, interconnectedness, and consistency among cities in the ASEAN region. These thematic concepts in the development of urban livability indicators would serve as operational basis for the prospective studies in working out the indexes that has to be constructed based on the three citymodels as basis for a comprehensive development of policy-driven urban livability indicators.

The study aims to develop appropriate urban indicators geared towards sustainable urban development that would serve as basic framework for evaluating urban livability of ASEAN secondary cities with Iskandar Malaysia in Malaysia, Davao City in the Philippines and the City of Makassar in Indonesia as city-models. The participation of expert-stakeholders from each city-model was sought to choose preliminary urban livability indicators through the study's framework-based indicators and supplementary indicators.

\section{METHODS}

The generic Delphi toolkit (Day and Bobeva, 2005) was used to obtain the most reliable statistical summary of the group responses (Dalkey and Helmer, 1963) and established adequate expert consensus to make a forecast or assignment of values believable or useful (Shields et al., 1987). The four key features for defining the procedure are: anonymity, iteration, controlled feedback, and the analyzed and statistical aggregation of group response (Rowe and Wright, 1999). The execution of a Delphi survey in this study secured a three-round iteration scheme. The primary and most significant process was the expert selection criteria, panel size, expertise, recruitment approach, and finally the establishment of members of the expert- panel which is composed of academicians with postgraduate qualifications (32\%), professionals/practitioners/NGOs (32\%), local government executives (33\%) and entrepreneurs (3\%). This study has a total of 60 experts from the three selected secondary cities where each was given equal representation with 20 experts.

First Round (Scoping Phase) - Survey questionnaires were sent to experts through e-mail and personal hand-in. Experts were to choose from the 76 sub- 
indicators, categorized under 11 domain indicators which are (a) Urban Infrastructure and Service, (b) Climate resilience and Disaster Preparedness, (c) Protection of Urban Environmental Resources, (d) Choices and Access to Quality Education, (e) Pubic Health and Wellness Services, (f) Social Equality and Security, (g) Urban Recreation and Accommodation Facilities, (h) Dynamism and Promotion of Local Economy, (i) Social Cohesion and Connectedness, (j) Ease in Urban Transportation and Mobility, (k) Good Governance, which they believe to be the most important urban livability indicators based on the framework. Additionally, they were asked to suggest supplemental sub-indicators which they saw fit under any of the domain indicators. The result as well as the analysis were initially performed and circulated to the expert-respondents in the second round. This phase has likewise determined the number of expertrespondents who participated in the survey which was significant information in terms of panel management.

Second Round (Convergence Phase) - The consolidated results of the scoping phase were circulated to the same panel of experts which were included in the second questionnaire. This phase has directed the experts to reconsider their choices of sub-indicators in the light of the consolidated results from the first round. Similarly, this round further requested the experts to state their preliminary degree of agreement (ranking) on the domain indicators using the 5-point Likert Scale ranging from $1=$ strongly disagree to $5=$ strongly agree .

Third Round (Consensus Phase) - Results of both the reconsidered choices of sub-indicators and the initial ranking of domain indicators were included in the final survey questionnaires. This phase has asked the experts to provide their degree of agreement on both the sub-indicators and the domain indicators using the 5-point Likert Scale. The use of the Likert Scale is consistent with Delphi scaling (McKnight et al., 1991) allowing the experts to rank the extent of their agreement with the indicators (Hemphill, et al., 2002).

To validate the consistency of the rankings and to normalize the weights, Kendall's $W$ coefficient of concordance (Wallis, 1939; Yeung et al., 2007; Donohoe, 2011) was used to determine the existence of an implicit agreement which necessarily indicates the existence of correlation (Altman and Bland, 1983). The ranking of indicators is statistically significant when $W=1$, while $W=0$ means all the experts ranked the indicators entirely dissimilar. (Altman and Bland, 1983).

\section{RESULTS}

First Round - The Scoping Phase

The scoping phase intends to gain a common understanding of the 11 domain indicators vis-à-vis its respective sub-indicators. Essentially, scoping determines 
M. Rafee Majid, G. Dario Pampanga, Noradila Ruslik, Musarrat Zaman, I.N. Medugu \& M.S. Amer

Urban Livability Indicators for Secondary Cities in ASEAN Region

merely the scope and content that takes forward the preliminary determination of significance made in screening to the next stage of the resolution (Weber and Ladkin, 2003). Thus, this initial process determines which sub-indicators are considered important and increases the likelihood of adequately prepared urban livability sub-indicators.

This phase has generated 108 urban livability sub-indicators which include 32 supplementary sub-indicators proposed by the panel of experts. The comportment of experts supplementing the framework-based indicators infers that there is a profound self-involvement in the generation of urban livability indicators which are reflective of the realities within the confines of their urban communities. This insightful supplementation by the panel of experts ran parallel to the precept that experts and social scientists have the most important facilitative role in establishing unanimity in the process of indicator development (Alibegovic and de Villa, 2008) and enhances credibility to the whole process (Hezri, 2004).

\section{Second Round - The Convergence Phase}

This round has allowed the selected sub-indicators in the scoping phase to undergo reconsideration by the experts as to its potency as suitable urban livability indicators. Of the 108 sub-indicators from The Scoping Phase, a total of 75 sub-indicators where 68 are framework-based and seven (7) are supplemental sub-indicators passed this Convergence Phase to be eligible for the final round. The inclusion of a sub-indicator to the final list was qualified through the 50\% frequency score cap. The supplemental indicators have provided greater foundation that subscribes to the concept of community ownership of the indicators. Simultaneously, preliminary determination of the degree of agreement of experts on 11 domain indicators was performed using the 5-point response alternatives of Likert Scale. Table 1 shows that the mode of each domain indicator indicates a conclusive summation that there exists a high degree of agreement among experts. The use of the mean is valuable to providing the overall average response. 
PLANNING MALAYSIA

Journal of the Malaysia Institute of Planners (2020)

Table 1. Preliminary Ranking of Domain Indicators

\begin{tabular}{|l|c|c|c|}
\hline \multicolumn{1}{|c|}{ Domain Indicators } & Mode & Mean & Overall rank \\
\hline Urban infrastructure and services & 5 & 4.9 & 1 \\
Protection of urban environmental resources & 5 & 4.65 & 2 \\
Good governance & 5 & 4.55 & 3 \\
Ease in urban transportation and mobility & 5 & 4.48 & 4 \\
Climate resilience and disaster preparedness & 5 & 4.47 & 5 \\
Public health and wellness services & 5 & 4.47 & 5 \\
Choices and access to quality education & 4 & 4.33 & 7 \\
Social equality and security & 4 & 4.23 & 8 \\
Urban services, recreation \& accommodation facilities & 4 & 4.22 & 9 \\
Dynamism and promotion of local economy & 4 & 4.17 & 10 \\
Social cohesion and connectedness & 4 & 3.78 & 11 \\
\hline Kendall's W=0.6274 & & \multicolumn{2}{|c}{ Source: Pampanga, 2017 }
\end{tabular}

The preliminary ranking of domain indicators was further put to test and validated by employing the non-parametric Kendall's $W$. After running the preliminary ranking, it yielded a coefficient of concordance $W$ of 0.6274 . The resulting level of concordance coefficient indicated a fair degree of agreement among the members of the panel of experts.

\section{Third and Final Round - The Consensus Phase}

The strength and validity of the concluding indicators has evolved with the use of fundamentally scientific approaches and some research complexities through established research methods and applied models. Throughout this study, the critical object was to develop appropriate urban livability indicators framework suitable for secondary cities in the ASEAN region through the consensus of expert-stakeholders from Iskandar Malaysia, Davao City and Makassar. Hence, the concept of operational indicators and the synthesizing of the set of indicators were substantially considered throughout this study. Table 2 shows the conclusive composite urban livability indicators for secondary cities in Southeast Asia with both the domain and sub-indicators ranked with corresponding weightings.

Table 2. Synthesis of Urban Livability Indicators for Secondary Cities in Southeast Asia

\begin{tabular}{|c|c|c|c|c|c|}
\hline Rank & Domain Indicator & Sub-indicator & Rank & $\begin{array}{c}\text { Kendall's } \\
W\end{array}$ & Weighting \\
\hline 1 & $\begin{array}{l}\text { Urban Infrastructure } \\
\text { and Services } \\
\text { (Weighting: } 0.10014)\end{array}$ & $\begin{array}{l}\text { affordable quality public housing } \\
\text { telecommunication with global network } \\
\text { safe and orderly sidewalks and overpasses } \\
\text { access to potable drinking water } \\
\text { availability of public spaces for public event } \\
\text { access to electricity } \\
\text { affordable house rentals }\end{array}$ & $\begin{array}{l}1 \\
2 \\
3 \\
4 \\
5 \\
6 \\
7\end{array}$ & 0.9357 & $\begin{array}{l}0.159 \\
0.151 \\
0.150 \\
0.139 \\
0.139 \\
0.138 \\
0.123\end{array}$ \\
\hline
\end{tabular}


M. Rafee Majid, G. Dario Pampanga, Noradila Ruslik, Musarrat Zaman, I.N. Medugu \& M.S. Amer

Urban Livability Indicators for Secondary Cities in ASEAN Region

\begin{tabular}{|c|c|c|c|c|c|}
\hline 2 & $\begin{array}{l}\text { Good Governance } \\
\text { (Weighting: 0.09911) }\end{array}$ & $\begin{array}{l}\text { accountable city officials } \\
\text { transparency in government transactions } \\
\text { local \& national laws properly implemented } \\
\text { government employee's performance } \\
\text { citizen participation in policy making process } \\
\text { responsive to needs of citizens }\end{array}$ & $\begin{array}{l}1 \\
2 \\
3 \\
4 \\
5 \\
6\end{array}$ & 0.7712 & $\begin{array}{l}0.179 \\
0.178 \\
0.176 \\
0.173 \\
0.151 \\
0.143\end{array}$ \\
\hline 3 & $\begin{array}{l}\text { Protection of Urban } \\
\text { Environmental } \\
\text { Resources } \\
\text { (Weighting: 0.09911) }\end{array}$ & $\begin{array}{l}\text { solid waste management system } \\
\text { air quality } \\
\text { drainage system } \\
\text { sanitary landfill } \\
\text { protection of natural waterways } \\
\text { water quality }\end{array}$ & $\begin{array}{l}1 \\
2 \\
3 \\
4 \\
5 \\
6\end{array}$ & 0.8182 & $\begin{array}{l}0.173 \\
0.167 \\
0.166 \\
0.166 \\
0.165 \\
0.163\end{array}$ \\
\hline 4 & $\begin{array}{l}\text { Ease in Urban } \\
\text { Transportation and } \\
\text { Mobility } \\
\text { (Weighting: } \\
\text { 0.09704) }\end{array}$ & $\begin{array}{l}\text { quality of urban transportation system } \\
\text { urban transport connectivity } \\
\text { quality of urban road network } \\
\text { availability of transport \& traffic mgmt system } \\
\text { alternative modes of urban mass transport } \\
\text { pedestrian sidewalks free from vendors } \\
\text { availability of bicycle lanes* } \\
\text { reasonable public transport fare } \\
\text { availability of road signs* }\end{array}$ & $\begin{array}{l}1 \\
2 \\
3 \\
4 \\
5 \\
6 \\
7 \\
8 \\
9\end{array}$ & 0.9266 & $\begin{array}{l}0.123 \\
0.122 \\
0.121 \\
0.115 \\
0.113 \\
0.112 \\
0.109 \\
0.093 \\
0.092\end{array}$ \\
\hline 5 & $\begin{array}{l}\text { Climate Resiliency } \\
\text { and Disaster } \\
\text { Preparedness } \\
\text { (Weighting: } 0.09257 \text { ) }\end{array}$ & $\begin{array}{l}\text { flood control system } \\
\text { availability of risk reduction facilities } \\
\text { citizen participation in risk assistance } \\
\text { availability of geo-hazard info. to citizens } \\
\text { disaster response system* }\end{array}$ & $\begin{array}{l}1 \\
2 \\
3 \\
4 \\
5\end{array}$ & 0.9425 & $\begin{array}{l}0.217 \\
0.206 \\
0.203 \\
0.193 \\
0.182\end{array}$ \\
\hline 6 & $\begin{array}{l}\text { Public Health and } \\
\text { Wellness Services } \\
\text { (Weighting: 0.09119) }\end{array}$ & $\begin{array}{l}\text { urban medical/health centres } \\
\text { availability of universal medical insurance* } \\
\text { ratio of medical officer to } 1000 \text { population } \\
\text { ratio of hospital bed to } 1000 \text { population } \\
\text { response to medical emergencies } \\
\text { average cost of hospital room/per day }\end{array}$ & $\begin{array}{l}1 \\
2 \\
3 \\
4 \\
5 \\
6\end{array}$ & 1.000 & $\begin{array}{l}0.183 \\
0.178 \\
0.166 \\
0.164 \\
0.159 \\
0.150\end{array}$ \\
\hline 7 & $\begin{array}{l}\text { Social Equality and } \\
\text { Security } \\
\text { (Weighting: 0.08878) }\end{array}$ & $\begin{array}{l}\text { crime rate incidence } \\
\text { well-lighted streets and thoroughfares } \\
\text { technology in crime response \& public safety } \\
\text { ratio of crime solution to crimes committed } \\
\text { access of differently-abled to establishments } \\
\text { crime prevention measures" } \\
\text { ratio of police to population }\end{array}$ & $\begin{array}{l}1 \\
2 \\
3 \\
4 \\
5 \\
6 \\
7\end{array}$ & 0.9739 & $\begin{array}{l}0.161 \\
0.159 \\
0.151 \\
0.138 \\
0.136 \\
0.131 \\
0.124\end{array}$ \\
\hline 8 & $\begin{array}{l}\text { Choices and Access } \\
\text { To Quality } \\
\text { Education } \\
\text { (Weighting: } 0.08465 \text { ) }\end{array}$ & $\begin{array}{l}\text { ratio of teachers with graduate level education } \\
\text { number of schools of higher learning } \\
\text { education centres for out-of-school youth } \\
\text { teacher-student ratio in elementary level } \\
\text { percent of high school drop-out }\end{array}$ & $\begin{array}{l}1 \\
2 \\
3 \\
4 \\
5\end{array}$ & 0.9661 & $\begin{array}{l}0.217 \\
0.215 \\
0.206 \\
0.194 \\
0.168\end{array}$ \\
\hline
\end{tabular}


PLANNING MALAYSIA

Journal of the Malaysia Institute of Planners (2020)

\begin{tabular}{|c|c|c|c|c|c|}
\hline 9 & $\begin{array}{l}\text { Urban Services, } \\
\text { Recreation and } \\
\text { Accommodation } \\
\text { Facilities } \\
\text { (Weighting: } 0.08465)\end{array}$ & $\begin{array}{l}\text { public markets } \\
\text { public parks } \\
\text { supermarkets } \\
\text { shopping malls } \\
\text { recreation centres } \\
\text { public library* } \\
\text { hotels/inns/lodging houses } \\
\text { religious facilities* }\end{array}$ & $\begin{array}{l}1 \\
2 \\
3 \\
4 \\
5 \\
6 \\
7 \\
8\end{array}$ & 0.7550 & $\begin{array}{l}0.138 \\
0.134 \\
0.138 \\
0.138 \\
0.138 \\
0.119 \\
0.108 \\
0.105\end{array}$ \\
\hline 10 & $\begin{array}{l}\text { Dynamism and } \\
\text { Promotion of Local } \\
\text { Economy } \\
\text { (Weighting: } 0.08396)\end{array}$ & $\begin{array}{l}\text { employment rate } \\
\text { growth rate of private investments } \\
\text { ease in business licensing for new enterprise } \\
\text { rates of local taxes } \\
\text { cost of rent of office space } \\
\text { average income } \\
\text { incentives to new investors } \\
\text { inflation rate } \\
\text { gross city domestic product per person }\end{array}$ & $\begin{array}{l}1 \\
2 \\
3 \\
4 \\
5 \\
6 \\
7 \\
8 \\
9\end{array}$ & 0.9313 & $\begin{array}{l}0.134 \\
0.127 \\
0.126 \\
0.111 \\
0.104 \\
0.103 \\
0.103 \\
0.097 \\
0.095\end{array}$ \\
\hline 11 & $\begin{array}{l}\text { Social Cohesion and } \\
\text { Connectedness } \\
\text { (Weighting: } 0.07811 \text { ) }\end{array}$ & $\begin{array}{l}\text { respect of tradition of diverse ethnic cultures } \\
\text { community resilience and adaptability } \\
\text { participation in social activities } \\
\text { religious tolerance* } \\
\text { sense of local community } \\
\text { volunteerism } \\
\text { access to social network }\end{array}$ & $\begin{array}{l}1 \\
2 \\
3 \\
4 \\
5 \\
6 \\
7\end{array}$ & 0.8962 & $\begin{array}{l}0.170 \\
0.153 \\
0.146 \\
0.145 \\
0.140 \\
0.130 \\
0.117\end{array}$ \\
\hline
\end{tabular}

*supplemental indicators

Source: Pampanga, 2017

In the summary results, all sets of sub-indicators were ranked with robust unanimity when tested with Kendall's $W$. Except for the sub-indicators under the domain indicator Public Health and Wellness Services with the perfect $W=1.000$ as shown in Table 2, the rest have relatively high $W$ 's ranging from 0.7712 (Good Governance) to 0.9739 (Social Equality and Security). It can be argued that the members of the expert panel have a collective view on indicators of urban livability with respect to the three city-models.

The domain indicators were also characterized with common properties as the sub-indicators. The mode in Rounds 2 and 3 remain relatively unchanged, while the mean scores vary insignificantly; this does so with the ranking of the domain indicators. Significantly important was the testing of the ranking through Kendall's $W$ which gave a higher degree of agreement with 0.8369 compared to 0.6274 in Round 2, implying the experts were finally in comparative consensus in the ranking of the domain indicators. Finally, corresponding weighting was performed as potential input to perform urban livability index.

Noteworthy that these urban livability indicators are the expressed desires generated via consensus of the survey respondents and are reflective of the needs of urban residents for improved quality of life. It neither serves the interest of transient visitors nor any multinational firms for purposes of relocating their executive staff; though it would most likely interest them. These indicators 
M. Rafee Majid, G. Dario Pampanga, Noradila Ruslik, Musarrat Zaman, I.N. Medugu \& M.S. Amer

Urban Livability Indicators for Secondary Cities in ASEAN Region

are basically transition boards for ASEAN cities towards building more livable and sustainable urban future.

\section{CONCLUSION AND RECOMMENDATION}

The concluding urban livability indicators framework characterizes the relative aspiration of citizens in Southeast Asia for livable urban society towards inclusive growth and sustainable development. It is unequivocally apparent that cities in the ASEAN region (as explicitly shown by the three city-models) share common and connected challenges in making livable and sustainable cities. The essentiality of ranking of the indicators convey baseline information of experts' urban knowledge, due to their profound exposure to urban environment and richer repertoire of various urban constructs, thereby professing deeper understanding to ensure a livable urban milieu.

In the ASEAN context, the unequivocal process of determining and ranking of domain indicators (with its respective sub-indicators) as shown in Table 2, has provided significant thematic priorities that would serve as a transition to spur action towards livable and sustainable urban cities. Apparently, the overriding argument of the challenges confronting the ASEAN urban communities is the necessity to improve its livability in the face of unrelenting urbanization; and in furtherance to have an inclusive comprehension as to how ASEAN can generate growth in the economy, including social equality and egalitarian economy.

The urban livability framework generated by this study can be expanded through the creation of a broad and integrated framework involving major cities and urban centers in the ASEAN is essential. This process involves the harmonization of significant issues and concerns that are considered vital in the promotion of urban livability and sustainability. Currently, there is the absence of a theoretically rigorous and empirically grounded framework to evaluate urban livability in the ASEAN perspective within the sustainability nexus of economic-social-environmental paradigm. At this instance, the development of an advanced ASEAN urban livability framework is thus imperative to define and measure urban livability and to determine where a city lies in its transition towards the achievement of its sustainability goals. Therefore, a comparative study on ASEAN cities' urban livability index is significantly imperative and this current study would basically serve as a preliminary platform. The livability index would substantially aid cities in member countries to have common benchmarks that would harmonize livability goals towards sustainability and competitiveness of One ASEAN.

Finally, the authors unequivocally believe that livability or sustainability principles are fundamental in shaping sustainable urbanization challenges and competitiveness of the ASEAN economic community today and the future. 
PLANNING MALAYSIA

Journal of the Malaysia Institute of Planners (2020)

\section{ACKNOWLEDGEMENT}

The authors would like to acknowledge the support of the Ministry of Education Malaysia through its Fundamental Research Grant Scheme (R.J130000.7852.5F065).

\section{REFERENCES}

Alibegovic D. J. \& De Villa, Z. K. (2008). The role of urban indicators in city management: a proposal for Croatian cities. Transition Studies Review. 15:63-80. Netherlands: Springer.

Altman, D.G. \& Bland, J.M. (1983). Measurement in medicine: The analysis of method comparison studies. Statistician. 32: 307-317.

Asian Development Bank (ADB) (2012). Key Indicators for Asia and the Pacific 2012 (43rd ed.) Mandaluyong City, Philippines: ADB 2012.

Asian Trends Monitoring. (2010). Good Water Governance Matter. Bulletin 15. Lee Kuan Yew School of Public Policy, Singapore.

Balsas, C. J. L. (2004). Measuring the livability of an urban center: an exploratory study of key performance indicators. Planning Practice \& Research, 19(1), 101-110. Carfax Publishing, Taylor \& Francis Ltd.

Chomistriana, D. (2011). Indonesia: Neighborhood Upgrading and Shelter Sector ProjectToward Cities without Slums. Inclusive Cities, Florian Steinberg and Michael Lindfield (eds). Asian Development Bank, (p. 47-63).

Dalkey, N.C.\& Helmer, O. (1963). An experimental application of the Delphi method to the use of experts. Management Science 9. 458-467.

Day, J. and Bobeva, M. (2005). A generic toolkit for the successful management of Delphi studies. The Electronic Journal of Business Research Methodology, 3(2), 103116.

Donohoe, H.M. (2011): A Delphi toolkit for ecotourism research, Journal of Ecotourism, $10: 1,1-20$

Food and Agriculture Organization of the United Nations (2002). Pressure-StateResponse Framework and Environmental Indicators. Retrieved from: http://www.fao.org/ag/againfo/ programmes/en/lead/toolbox/refer/envindi.htm

Friedman, M. (2005). Trying Hard is not Enough. How to Produce Measurable Improvements for Customers and Communities. Trafford Publishing.

Hemphill, J., McGreal, S. and Berry, J. (2002): An aggregated weighting system for evaluating sustainable urban regeneration. Journal of Property Research. 19(4), 353-373.

Hezri, A. A. (2004). Sustainability indicator system and policy processes in Malaysia: a framework for utilization and learning. Journal of Environmental Management. 73:357-371.

Ji, B. (2006). The Livable City: The Chinese Perspective and a Plan for Beijing. CPAFFC. (p. 12). Beijing.

Kapoor, A. (2011). Livability Index 2011: The Best Cities in India. Institute for Competitiveness. Development Management Institute, Gurgaon: India

Litman, T. (2011). Sustainability and Livability: Summary of Definitions, Goals, Objectives, and Performance Indicators. Victoria Transport Policy Institute. 
M. Rafee Majid, G. Dario Pampanga, Noradila Ruslik, Musarrat Zaman, I.N. Medugu \& M.S. Amer

Urban Livability Indicators for Secondary Cities in ASEAN Region

Pampanga, D. (2017). Urban Livability Indicators for Secondary Cities in Southeast Asia. Unpublished Thesis. Department of Urban and Regional Planning. Faculty of Built Environment, Univesity Teknologi Malaysia, Johor Bahru, Malaysia.

Rowe, G. and Wright, G. (1999). The Delphi technique as a forecasting tool: issues and analysis. International Journal of Forecasting. 15 (1999) 353-375. Elsevier.

Shaffer D. and Vollmer, D. (2010). Pathways to Urban Sustainability: Research and Development on Urban Systems: Summary of a Workshop. National Research Council of the National Academies. The National Academic Press. Washington, D. C.

Steinberg, F. (2011). Philippines: Strategic Private Sector Partnerships for Urban Poverty Reduction in Metro Manila. Inclusive Cities, F. Steinberg and M. Lindfield (eds). Metro Manila, Philippines: Asian Development Bank, (p. 64-82).

Timmer, V. and Seymoar N. K. (2005). The Livable City. World Urban Forum 2006 for Sustainable Cities. Vancouver Working Grp Discussion Paper. Inter. Center. Canada.

Tran, Hoai-Anh and Yip, Ngai-Ming (2008). Caught between plan and market: Vietnam's Housing Reform in the transition to market economy. Urban Policy Research. 26(3), 309-323.

UN-HABITAT (2010). The State of Asian Cities 2010/2011. UN Human Settlements Programme (UN-HABITAT) Regional Office for Asia and the Pacific, Japan.

Vliet, Willem van. (2002). Cities in a Globalizing World: From Engines of Growth to Agents of Change. Environment \& Urbanization. Vol. 14. No. 1 April 2002.

Wallis, W.A. (1939). The correlation ratio for ranked data. Journal of American Statistics Association. 34: 533-538.

Weber, K. and Ladkin, A. (2003). The convention industry in Australia and the UK: Key issues and competitive forces. Journal of Travel Research. 42, 125-132.

Yeung, J.F.Y., Albert P. C., Chan, A.P.C., Daniel W. M., Chan, D.W.M. and Li, L.K. (2007). Development of a partnering performance index (PPI) for construction projects in Hong Kong: a Delphi study. Construction Management and Economics. 25:12, 1219-1237

Received: January 2020. Accepted: $14^{\text {th }}$ May 2020 